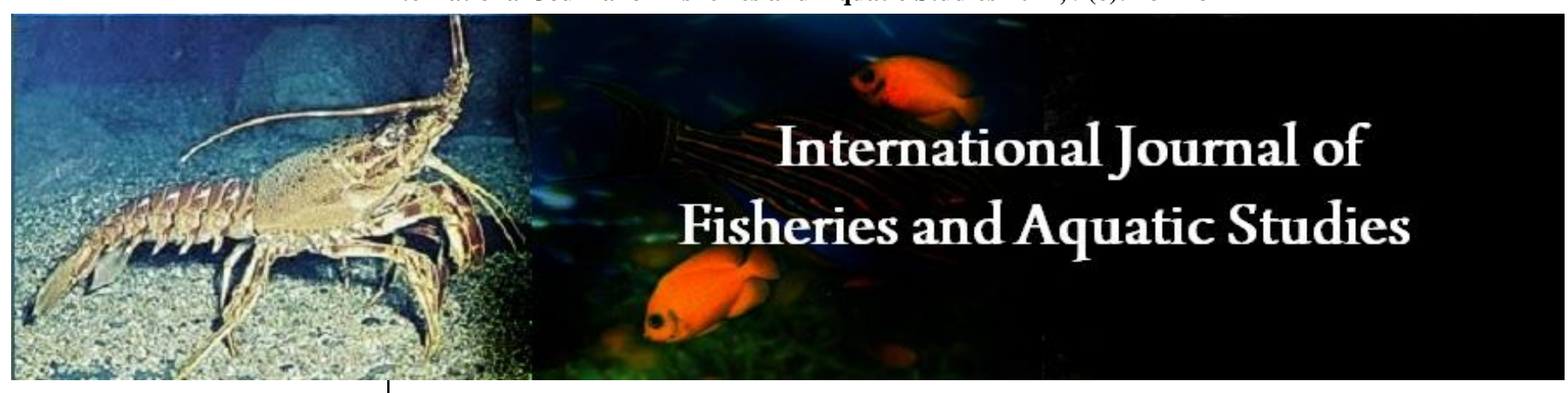

E-ISSN: 2347-5129

P-ISSN: 2394-0506

(ICV-Poland) Impact Value: 5.62

(GIF) Impact Factor: 0.549

IJFAS 2021; 9(6): 282-287

(C) 2021 IJFAS

www.fisheriesjournal.com

Received: 07-09-2021

Accepted: 09-10-2021

Mark Ariel D Malto

Magallanes Campus, Sorsogon

State University, Philippines

Antonino B Mendoza

Graduate Studies, Bicol

University Tabaco Campus,

Philippines

Plutomeo M Nieves

Graduate Studies, Bicol

University Tabaco Campus,

Philippines

Renan U Bobiles

Graduate Studies, Bicol

University Tabaco Campus,

Philippines

Alex P Camaya

Graduate Studies, Bicol

University Tabaco Campus,

Philippines

Skorzeny De Jesus

Graduate Studies, Bicol

University Tabaco Campus,

Philippines

Corresponding Author:

Mark Ariel D Malto

Magallanes Campus, Sorsogon

State University, Philippines

\section{Abundance and characteristics of microplastic in cultured green mussels Perna viridis in Sorsogon Bay, Philippines}

\author{
Mark Ariel D Malto, Antonino B Mendoza, Plutomeo M Nieves, Renan U \\ Bobiles, Alex P Camaya and Skorzeny De Jesus
}

DOI: $\underline{\text { https://doi.org/10.22271/fish.2021.v9.i6d.2612 }}$

\begin{abstract}
Microplastic ingestion by marine organisms is becoming an emergency threat to seafood industry, with farmed mussels as of particular interest. The context of trophic transfer accords that humans are at large into exposure to microplastic through its consumption. In the province of Sorsogon, Philippines, green mussel Perna viridis is sorted into various 'grading label': Small $(5.0-6.9 \mathrm{~cm})$, Medium $(7.0-8.9 \mathrm{~cm})$ and Jumbo $(\geq 9.0 \mathrm{~cm})$ and are marketed within and outside the province. Total microplastic varied from 0.31 to 2.5 items/ individual. Mussel size ranged from 5.0-6.9 $\mathrm{cm}$ showed the highest microplastics (2.57 items/ individual) while mussels below $2.9 \mathrm{~cm}$ has the least microplastic $(0.31$ item/individual). The majority of ingested microplastics were lines, while their colors and sizes varied. Fourier Transform Infrared Spectroscopy (FT-IR) indicated organosiloxane and polyethylene terephthalate as the most common polymer type identified. The results suggested that microplastics detected in the mussels are relatively within the narrow range with no significant differences of its distribution across its categorical sizes. With the results can be used as a baseline contribution for the risk assessment of microplastic pollution in Sorsogon bay.
\end{abstract}

Keywords: microplastic, FTIR, mussel, Sorsogon

\section{Introduction}

Previous studies have implicated the Philippines as one of the highest contributors of plastics to the marine environment ranking 3rd, contributing $0.28-0.75$ million metric tons of marine plastic per year (Jambeck et al., 2015; Lebreton et al. 2017) ${ }^{[1,2]}$. Microplastics, defined as plastic materials or fragments $<5 \mathrm{~mm}$, are most likely the most numerically abundant plastic debris items in the ocean today (Law and Thompson, 2014) ${ }^{[3]}$. The quantities of microplastics will inevitably increase due to the degradation of large, single plastic items, ultimately breaking down into millions of microplastic pieces (Cozar et al., 2014) ${ }^{[4]}$.

One of the primary environmental risks associated with microplastics is their bioavailability to marine organisms (Wright et al., 2013; Desforges et al., 2015) ${ }^{[5,6]}$. Green Mussel Perna viridis are of particular interest because they are cosmopolitan species, sedentary and have extensive filter-feeding nature exposing them directly to chemicals and pollutants present in the water column. Microplastic effects to different marine organisms have been already recorded, compromising them into physiological consequences. And into context of trophic transfer, the humans are at large into exposure to microplastic through the consumption of these seafood (Farrell and Nelson, 2013; Watts et al., 2014) ${ }^{[7,8]}$.

This bivalve species is also not new in the province of Sorsogon, having its fisheries industry for several decades. Its cultivation is considered to be as one of the country's top mussel producers. Its market in the province are sorted into various 'grading label: Small $(5.0-6.9 \mathrm{~cm})$, Medium $(7.0-8.9 \mathrm{~cm})$ and Jumbo $(\geq 9.0 \mathrm{~cm})$. And is mostly exported outside the province while the rest of its production is locally consumed. Sizes below $5.0 \mathrm{~cm}$ are likewise being retailed to fishpond operators as trash feed for their mangrove crab culture and to fishermen as bait to their fishing. Suggesting that the size of the shell is usually important, and not how much mussel meat is in. Thus, this study was proposed to identify characterize and quantify 
microplastics found in different sizes of cultured green mussels $P$. viridis in Sorsogon Bay, Philippines.

\section{Materials and Methods}

\section{Sample Collection and Sampling Sites}

A total of one-hundred fifty mussel $P$. viridis were collected from three sites along the coastal water of Sorsogon bay from January to March 2021 (Table 1). The samples were directly collected from the sites using stainless steel scalpels and forceps (Figure 1). In order to provide an ample representation of the bay, sampling sites were haphazardly selected from three mussel farm sites. Fifty mussels from each farm site (ten individuals per size category) were collected and was transferred to the laboratory for microplastic analysis.

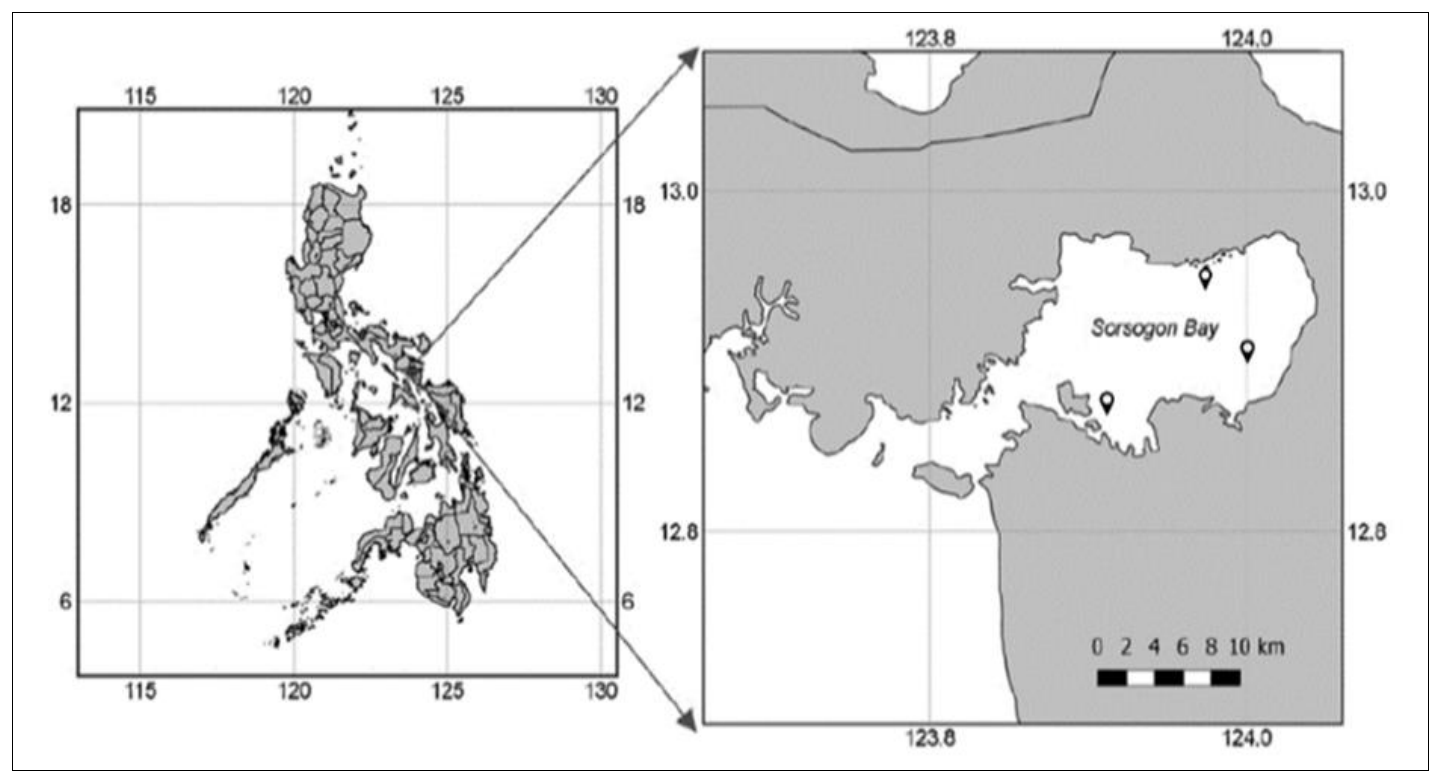

Fig 1: Sorsogon Bay located within the Philippines and zoomed in showing the sampling sites in Sorsogon City, in the municipality of Casiguran and in the municipality of Juban, Sorsogon, Image from Yñiguez et al., $2018{ }^{[9]}$.

Table 1: Length and weight and microplastic abundance in $P$. viridis

\begin{tabular}{|c|c|c|c|c|c|}
\hline $\begin{array}{c}\text { P. viridis size } \\
\text { category }(\mathbf{c m})\end{array}$ & $\begin{array}{c}\text { Number of } \\
\text { individuals }\end{array}$ & $\begin{array}{c}\text { Shell length } \\
(\mathbf{c m})\end{array}$ & $\begin{array}{c}\text { Soft tissue weight }(\mathbf{g} / \\
\text { individual) }\end{array}$ & $\begin{array}{c}\text { Number of items/ } \\
\text { individual }\end{array}$ & $\begin{array}{c}\text { Number of items/g } \\
\text { wet weight }\end{array}$ \\
\hline$<2.9$ & 30 & $2.37 \pm 0.07$ & $0.37 \pm 0.03$ & $0.3056 \pm 0.03$ & $0.8351 \pm 0.16$ \\
\hline $3.0-4.9$ & 30 & $3.93 \pm 0.09$ & $1.88 \pm 0.13$ & $2.0833 \pm 0.29$ & $1.1454 \pm 0.26$ \\
\hline $5.0-6.9$ & 30 & $5.65 \pm 0.11$ & $4.58 \pm 0.32$ & $2.5033 \pm 0.35$ & $0.4217 \pm 0.06$ \\
\hline $7.0-8.9$ & 30 & $7.27 \pm 0.07$ & $6.45 \pm 0.30$ & $1.9667 \pm 0.29$ & $0.2760 \pm 0.04$ \\
\hline$>9.0$ & 30 & $9.39 \pm 0.06$ & $9.85 \pm 0.12$ & $2.3333 \pm 0.39$ & $0.2313 \pm 0.04$ \\
\hline
\end{tabular}

\section{Quality assurance and quality control}

To avoid contamination, all of the liquid (freshwater, saltwater and hydrogen peroxide) were filtered with $1 \mathrm{~mm}$ filter paper prior to use. All of the containers and beakers were rinsed three times with filtered water. The samples were immediately covered if they were not in used. All of the experimental procedures were finished as soon as possible.

\section{Hydrogen peroxide treatment}

The shell length and weight of each bivalve were recorded. Each sample was pooled into $\sim 5 \mathrm{~g}$ of soft tissue each $(\mathrm{Li}$ et al., 2015 and $\mathrm{Li}$ et al., 2016) ${ }^{[10]}{ }^{[11]}$. Approximately $200 \mathrm{~mL}$ of $30 \% \mathrm{H}_{2} \mathrm{O}_{2}$ was added to each bottle to digest the organic matter. The bottles were covered and placed in a drying oven at $65{ }^{\circ} \mathrm{C}$ for $24 \mathrm{~h}$ and then at room temperature for $24-48 \mathrm{~h}$ to extend the digestion effect of the soft tissue.

\section{Floatation and filtration with saline $(\mathrm{NaCl})$ solution}

A concentrated saline solution was prepared to separate the microplastics from dissolved liquid of the soft tissue via floatation. Approximately $800 \mathrm{~mL}$ of filtered $\mathrm{NaCl}$ solution was added to each bottle. The liquid was mixed and retained overnight. The overlying water was directly filtered over Whatman filter paper using a vacuum system. Then the filter were placed into clean petri dishes with a cover for further analysis.

\section{Observation of microplastic}

The filters were observed under OPTIKA LAB-20 stereomicroscope and OPTIKA B-290TB digital inspection microscope powered by PROVIEW v.4.815674.20191008 for imaging, particle size and shape identification and quantification. Colors were identified using Colors.exe software (Otaka et al. 2002) ${ }^{[12]}$ adopting the 12 basic color terms of the ISCC-NBS (Inter-Society Color Council National Bureau of Standards) System of Color Designation as recommended by Kershaw et al. (2019) ${ }^{[13]}$. A proportion of $10 \%$ from all of the samples visually examined were validated through Attenuated Total Reflectance (ATR) Fourier Transform Infrared (FTIR) Spectroscopy (Perkin Elmer FTIR Spectrometer Frontier).

\section{Statistical analysis}

Statistical test for normality was performed using the SPSS version 25.0 and a confidence level of $95 \%(p=0.05)$. Shell length $(\mathrm{cm})$, shell weight $(\mathrm{g})$ and soft tissue weight $(\mathrm{g})$ were presented as mean \pm standard error. One-Way ANOVA test were performed to determine the significant differences of the 
items/ individual and items/ $\mathrm{g}_{\text {wet weight }}$ among the categories of $P$. viridis sizes.

\section{Results}

\section{Characteristics of microplastic in $\mathbf{P}$. viridis}

Multiple types of microplastic, including fragments, foams, films, lines and pellets, occurred in the tissues of $P$. viridis.
Lines were the most popular microplastic shape and consisted $67 \%$ of the total microplastic found on the different class sizes of green mussel. Pellet were the least common shape and were not observed at all except for mussels with sizes $3.0-$ $4.9 \mathrm{~cm}$. Lines were only found exclusively in the mussels with sizes below $2.9 \mathrm{~cm}$ (Figure 2).
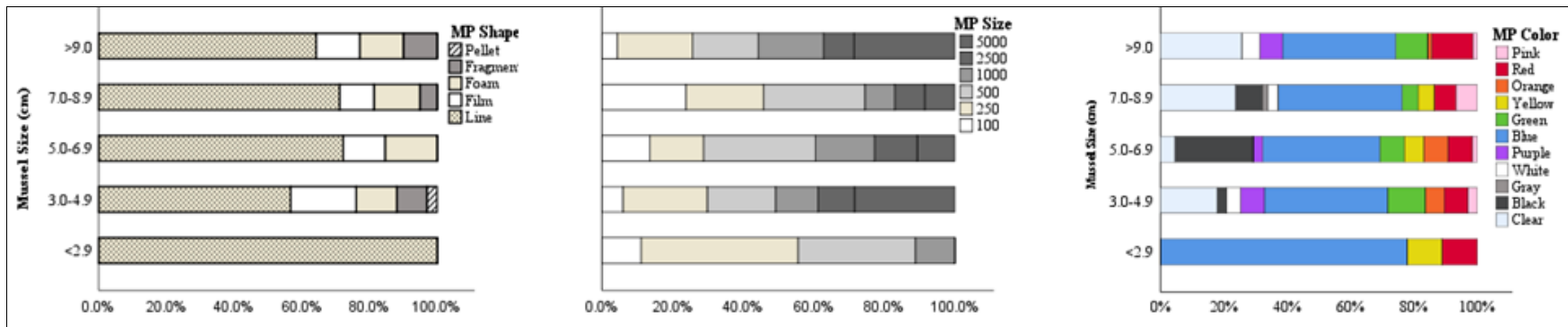

Fig 2: Characteristics of microplastic found in $P$. viridis of Sorsogon bay in terms of (a) shape; (b) size; and (c) color.

The most diverse colors were observed in lines followed by films. With the most popular colors blue, transparent, red, green and black. Overall the lines were usually blue and transparent. The size of the microplastics ranged from $100 \mu \mathrm{m}$ to $5 \mathrm{~mm}$ in the bodies of the green mussel were examined. Microplastics with sizes $250 \mu \mathrm{m}$ and $500 \mu \mathrm{m}$ were the most common in green mussels, each consisting $25 \%$ of the microplastics calculated (Figure 2).

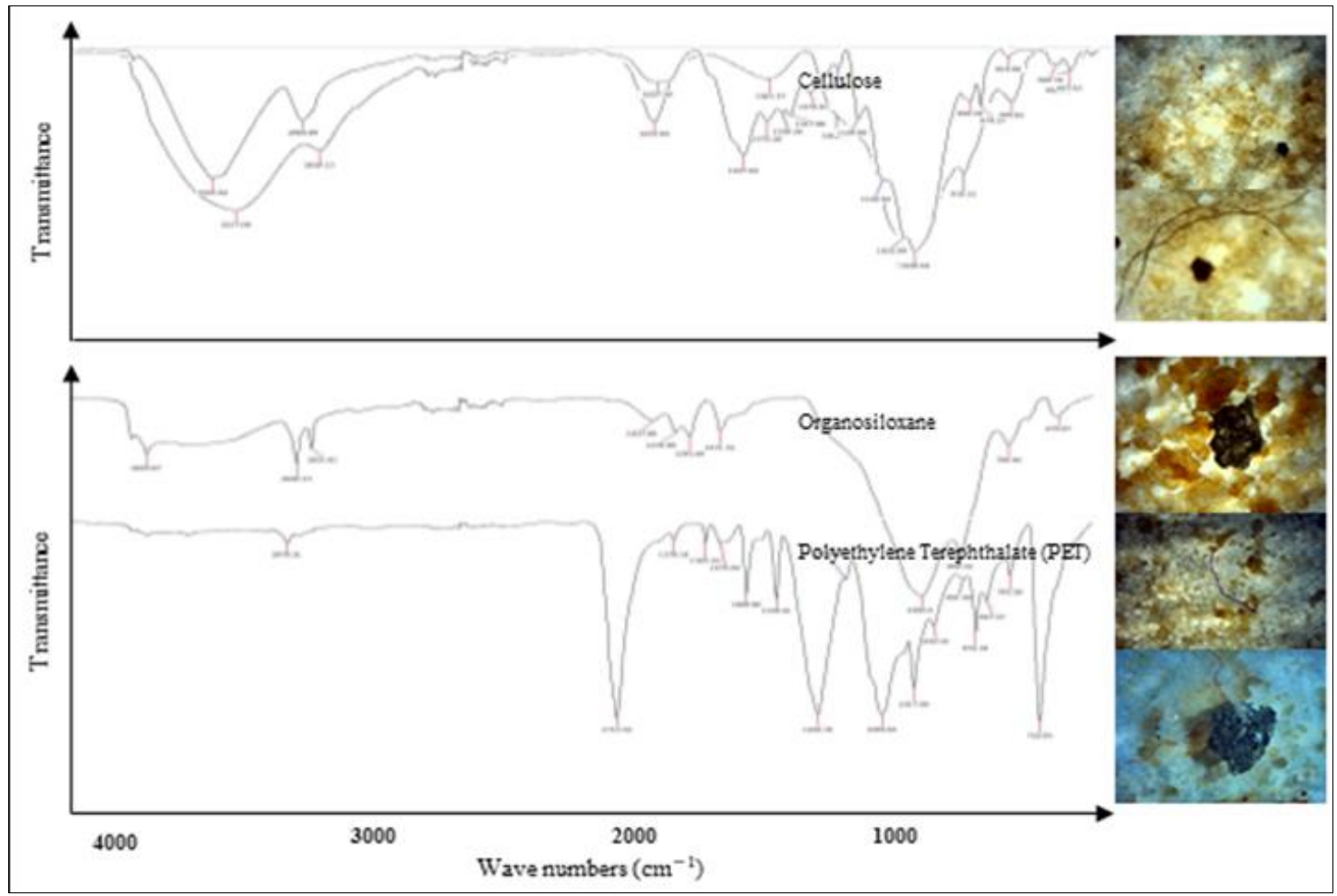

Fig 3: (a) Identification of micro plastics with Attenuated Total Reflectance - Fourier transformed Infrared Spectroscopy (ATR-FTIR). The measurements in the figure were performed under the transmittance mode. (b) Photographs of different types of microplastic found the $P$. viridis of Sorsogon bay.

Of the visually identified microplastic, $10 \%$ of these particles were validated for ATR-FTIR analysis. Of this subsample, only $62 \%$ were identified as microplastic composing $24 \%$ organosiloxane and $33 \%$ polyethylene terephthalate (PET) or polyester fiber. Natural fiber identified were cellulose materials composing $43 \%$ of the total samples.

\section{Abundance of microplastic in $P$. viridis}

The number of total microplastic varied from 0.31 to 2.5 items/ individual and from 0.23 to 1.15 items/ $\mathrm{g}_{\text {wet weight }}$ Mussel ranging the size of 5.0-6.9 $\mathrm{cm}$ showed the highest detected microplastics (2.57 items/ individual) while mussels with sizes below $2.9 \mathrm{~cm}$ has the least ( 0.31 item/individual). One-way ANOVA revealed that there was no significant differences found on the number of items per individual across its class sizes $F(4,91)=0.95, p=0.44$ but not with the number of items per tissue weight $F(4,91)=15.32, p=0.00$. (Figure 4).A Tukey post hoc test revealed that the microplastic item in soft tissues of green mussels was significantly lower in class size $5.0-6.9 \mathrm{~cm} \quad(0.42 \pm 0.06$ item $/ \mathrm{g}_{\text {wet }}$ weigh, $\left.p=0.00\right)$, class size $7.0-8.9 \mathrm{~cm} \quad(0.28 \pm 0.04$ item $/ \mathrm{g}_{\text {wet }}$ weigh, $\left.p=0.00\right)$ and class size $>9.0 \mathrm{~cm}(0.23 \pm 0.04$ 
item $\left./ \mathrm{g}_{\text {wet weigh }}, p=0.00\right)$ compared to class size $3.0-4.9 \mathrm{~cm}$ $\left.\left(1.14 \pm 0.26 \mathrm{item} / \mathrm{g}_{\text {wet weigh }} p=0.77\right)\right)$. There is no statistically significant difference between the class size $3.0-4.9 \mathrm{~cm}$ and class size $<2.9 \mathrm{~cm}\left(0.83 \pm 0.23\right.$ item $\left./ \mathrm{g}_{\text {wet weigh }} p=0.77\right)$ (Figure 4).

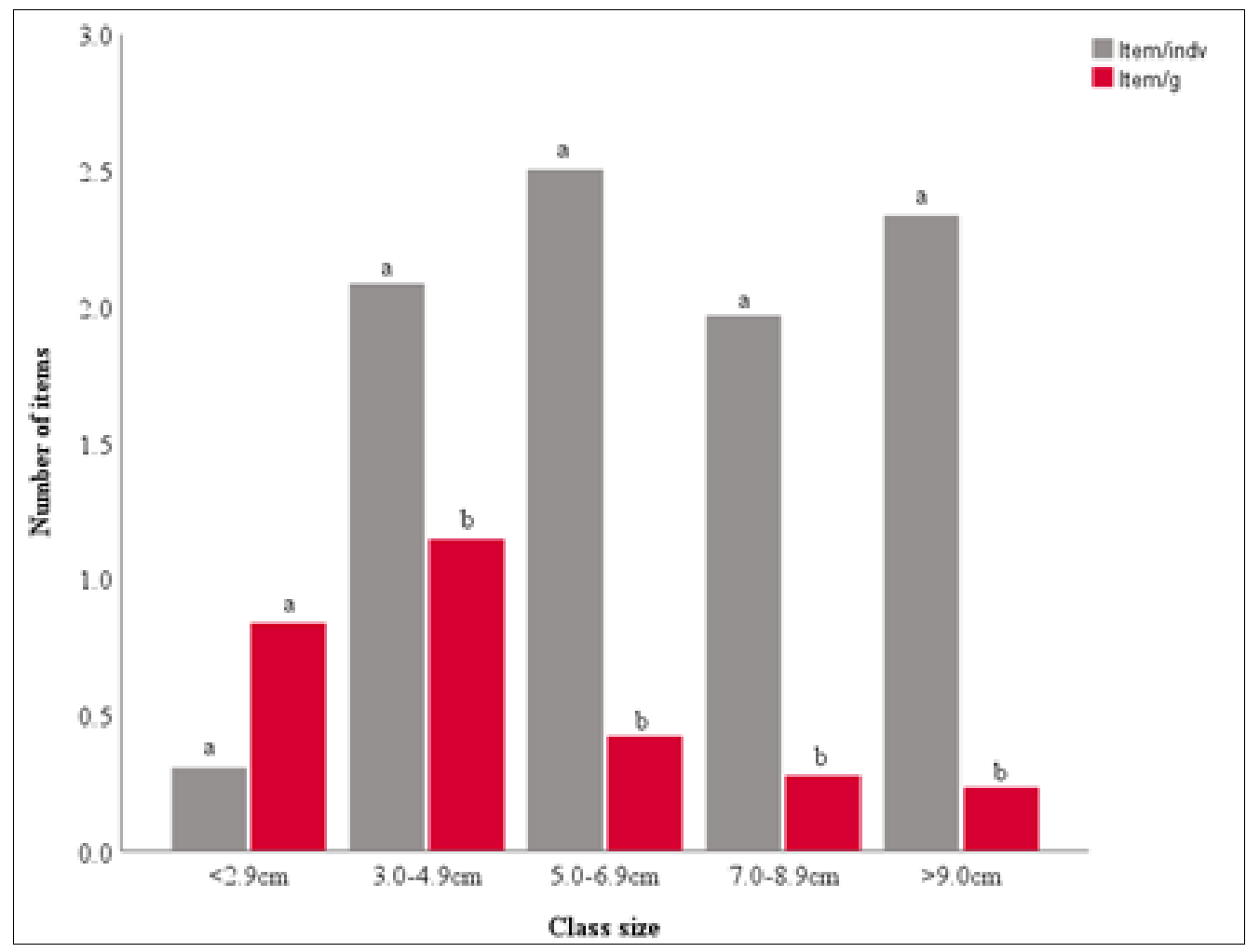

Fig 4: Mean abundance of microplastics. The letters ( $a$ and $b$ ) indicate the results of One-way ANOVA. Bars with the same letters indicates no significant difference.

\section{Discussion}

We found that microplastic pollution was detected in different aquaculture farms in Sorsogon bay. Compared to other published literature, the level of microplastic in Sorsogon Bay were approximately lower (Table 2). In terms of variation, we predicted more microplastic in larger mussels. As expected microplastic abundance (item/ individual) in the larger mussels were relatively higher than the smallest sizes. In contrast, when microplastic abundance were considered as (items/ $\mathrm{g}_{\text {wet weight }}$ ), the highest microplastic abundance was in $3.0-4.9 \mathrm{~cm}$ size class and was low in the largest mussel $(>9 \mathrm{~cm})$. This was because the mean number of microplastic per mussel was relatively consistent $(\sim 0.3$ items/ individual) across the largest mussels $(5.0-6.9,7.0-8.9,9.0+\mathrm{mm})$, even as mass was higher in the larger mussels. Moreover, there is no correlation both on the items found per individual $r_{s}(94)=0.048, p=0.646$ and on the number of items per soft tissue weight $r_{s}(94)=-0.070, p=0.496$.

Table 2: Comparison of microplastic pollution in bivalves $\mathrm{n}$ the present study vs the previous studies.

\begin{tabular}{|c|c|c|c|c|c|}
\hline Species and sources & $\begin{array}{c}\text { Treatment } \\
\text { method }\end{array}$ & Identification method & $\begin{array}{c}\text { Types of } \\
\text { microplastic }\end{array}$ & Levels of microplastic & References \\
\hline $\begin{array}{l}\text { Perna viridis } \\
\text { Philippines }\end{array}$ & $30 \% \mathrm{H}_{2} \mathrm{O}_{2}$ & $\begin{array}{c}\text { Visual identification and verified with } \\
\text { ATR-FTIR } \\
\end{array}$ & Lines (fibers) & $\begin{array}{c}0.3-2.5 \text { items/ } \\
\text { individual }\end{array}$ & This study \\
\hline $\begin{array}{l}\text { Perna viridis } \\
\text { Philippines }\end{array}$ & $30 \% \mathrm{H}_{2} \mathrm{O}_{2}$ & $\begin{array}{c}\text { Visual identification and verified with } \\
\text { ATR-FTIR }\end{array}$ & Lines (fibers) & $\begin{array}{c}0.23-1.15 \\
\text { items/g wet weight }\end{array}$ & This study \\
\hline $\begin{array}{l}\text { Perna viridis } \\
\text { Philippines }\end{array}$ & $30 \% \mathrm{H}_{2} \mathrm{O}_{2}$ & Visual identification & Fibers & $\begin{array}{c}0.27-0.41 \\
\text { items/g wet weight }\end{array}$ & \begin{tabular}{|} 
Bilugan et al., 2021 \\
{$[14]$}
\end{tabular} \\
\hline $\begin{array}{l}\text { Perna viridis } \\
\text { Vietnam }\end{array}$ & $10 \% \mathrm{KOH}$ & $\begin{array}{c}\text { Visual identification and verified with } \\
\text { an } \mu \text {-FT-IR }\end{array}$ & Fibers & 2.6 items/ individual & $\begin{array}{l}\text { Nam, P.N. et al., } \\
2019 \text { [15] }\end{array}$ \\
\hline $\begin{array}{l}\text { Perna viridis } \\
\text { China } \\
\end{array}$ & $30 \% \mathrm{H}_{2} \mathrm{O}_{2}$ & LUMOS microscopy ATR mode & Fibers & $\begin{array}{c}0.77-8.22 \text { items } \\
\text { individual } \\
\end{array}$ & Qu et al., $2018^{[16]}$ \\
\hline $\begin{array}{c}\text { Mytilus edulis } \\
\text { United Kingdom }\end{array}$ & $30 \% \mathrm{H}_{2} \mathrm{O}_{2}$ & $\begin{array}{c}\text { Visual identification and verified with } \\
\text { an } \mu \text {-FT-IR }\end{array}$ & Fibers & $\begin{array}{c}1.1-6.4 \\
\text { items/individual }\end{array}$ & Li et al., $2018^{[17]}$ \\
\hline $\begin{array}{l}\text { Mytilus edulis } \\
\text { China }\end{array}$ & $30 \% \mathrm{H}_{2} \mathrm{O}_{2}$ & $\begin{array}{c}\text { Visual identification and verified with } \\
\text { an } \mu \text {-FT-IR }\end{array}$ & Fibers & $\begin{array}{c}1.5-7.6 \\
\text { items/individual }\end{array}$ & Li et al., $2016^{[11]}$ \\
\hline $\begin{array}{c}\text { Mytilus } \\
\text { galloprovincialis } \\
\text { Northern Ionian Sea }\end{array}$ & $30 \% \mathrm{H}_{2} \mathrm{O}_{2}$ & $\begin{array}{c}\text { Visual identification and verified with } \\
\text { ATR-FTIR }\end{array}$ & Fibers, fragments & $\begin{array}{l}1.95 \pm 1.14 \\
\text { items/individual }\end{array}$ & $\underset{[18]}{\operatorname{Digka} \text { et al., }} 2018$ \\
\hline
\end{tabular}

In case of seafood safety, the number of microplastic is useful than total mass. Following exposure diet, consumers purchasing mussels of grading label small to jumbo sizes (5.0$\geq 9.0 \mathrm{~cm}$ ) would likely to ingest $\sim 44$ to $\sim 23$ particles per $100 \mathrm{~g}$ 
portion. If accounting for a $57 \%$ representation for the actual microplastic found on this study, this results in to $\sim 24$ to $\sim 13$ microplastic particles per $100 \mathrm{~g}$. This number is comparably smaller to the $\sim 70$ microplastic particles per $100 \mathrm{~g}$ portion of microplastic in UK supermarkets. According to EFSA statement, only microplastics smaller than $150 \mu \mathrm{m}$ may translocate across the human gut epithelium (EFSA CONTAM Panel, 2016) ${ }^{[19]}$ which equates to an estimated $15 \%$ of the particles recovered from farmed mussels of Sorsogon Bay (figure 2) and the absorption of these penetrating organs may be limited to $\leq 0.3 \%$ (EFSA CONTAM Panel, 2016) ${ }^{[19]}$. Likewise, on the initial study of Catarino et al., $2018^{[20]}$, the risk of plastic ingestion via mussel consumption is minimal when compared to fiber exposure during a meal via dust fallout in a household.

This detection of microplastic on farmed green mussels of Sorsogon bay, only suggest the increasing evidence of microplastic contamination to this known seafood, and its entry to our diet is a function of the waste that we disposes of. Despite majority of identified microfibers were cellulose, probably from biodegradable textile cottons, its effect to human ingestion is still lacking.

Organosiloxanes is an evidence of possible waste from silicon-containing products such as baking utensils and pans, baby nipples, and pacifiers, medical devices and implants, water-repellent windshield coating, construction lubricants and sealants as well as deodorant creams and moisturizers. The primary health concerns associated with siloxanes have focused primarily on $\mathrm{D}_{4}$ and $\mathrm{D}_{5}$ compounds that are toxic and bioaccumulative. Siloxane products can be avoided through reading product labels and purchasing toxic-chemical free cookware alternative like glass or ceramics (Meghan J, 2021) [21]. Polyethylene terephthalate (PET) detection are also daunting, which are mainly used in the plastic industry. PET has become widely used in the plastic industry as resin form for plastic bottles, food jars, food trays and as fiber form for textiles (known as polyester), monofilament, carpet, and films. While it is generally considered a "safe" plastic, and does not contain BPA, in the presence of heat it can leach antimony trioxide and phthalates. Both of these are dangerous to health. While antimony may contribute to menstrual and pregnancy issues, phthalates are endocrine disruptors (Filella M, 2020) ${ }^{[22]}$.

With this findings, it indicates that there is a haphazard wastemismanagement introduction of this plastic wastes into the bay. Its prevalence should be investigated and its waste management practices should be revisited both on land and in the shoreline.

Since human health consequences of different types of microplastic in seafood are still evolving, its detection in this kind of seafood is worth considering. Especially that public perception on the risk from microplastics are increasing as agitated in media. If consumers perceive that the seafood contain microplastics, there is a potential that their interpretation of the relative risks involve may result in behavioral change or in the reduction of seafood consumption. Clearly, this would result in the loss of income in the seafood industry, and loss of safe nutritious protein for consumers (Bergmann et al., 2015) ${ }^{[23] .}$

Though this marine pollution concern is ubiquitous and increasingly evident, with Sorsogon bay is clearly no exception to this paradigm, this evidence of microplastic occurrence in the farmed green mussels of Sorsogon bay of varying grading label on its market will hopefully drive effective social perception and behavioral change work on supporting measures addressing the issue.

\section{Conclusion and Recommendation}

The study investigated the abundance and characteristics of microplastic in cultured green mussels in Sorsogon Bay. Commercially marketed into various 'grading label': small, medium and jumbo, the species was detected with microplastic. Primary results from the study were, (i) low abundance of microplastic, as compared to other published literatures with no significant differences on the microplastic items per individual on various 'grading label' but not on microplastic items per soft tissue weight (ii) lines or fibers dominated the microplastic shape, blue as the most popular color, $250 \mu \mathrm{m}$ to $500 \mu \mathrm{m}$ as the most common microplastic size and organosiloxanes and polyethylene terephthalate (PET) were the detected polymer types. Its detection to cultured green mussels in Sorsogon bay is an evidence that the bay is no exception to this ubiquitous type of marine pollution. Indicating that there is a haphazard wastemismanagement introduction into the bay needing visitation and investigation. Since public perception on seafoodcontaining microplastic can lead to their behavioral change in seafood consumption, perception survey should be conducted in preparation for the risk-assessment of microplastic occurrence in commercial bivalves of Sorsogon bay.

\section{References}

1. Jambeck JR, Geyer R, Wilcox C, Siegler TR, Perryman M, Andrady A, et al. Plastic waste inputs from land into the ocean. Science. 2015;347:768-71.

2. Lebreton LCM, van der Zwet J, Damsteeg J, Slat B, Andrady A, Reisser J. River plastic emissions to the world's oceans. Nature Communications. 2017;8:15611.

3. Law KL, Thompson RC. Microplastic in the seas. Science. 2014;345:144-5.

4. Cozar A, Echevarria F, Gonzalez-Gordillo JI, Irigoien X, Ubeda B, Hernandez-Leon S, et al. Plastic debris in the open sea. Proceedings of the National Academy of Sciences. 2014;111(28):10239-10244.

5. Wright SL, Thompson RC, Galloway TS. The physical impacts of microplastics on marine organisms: a review. Environmental Pollution. 2013;178:483-492.

6. Desforges JW, Galbraith M, Ross PS. Ingestion of microplastics by zooplankton in the Northeast Pacific Ocean. Arch. Environ. Contam. Toxicol. 2015;69:320330. http://dx.doi.org/10.1007/s00244-015-0172-5.

7. Farrell P, Nelson K, Trophic level transfer of microplastic: Mytilus edulis (L.) to Carcinus maenas (L.). Environmental Pollution. 2013;177:1-3. https://doi.org/10.1016/j.envpol.2013.01.046.

8. Watts AJR, Lewis C, Goodhead RM, Beckett SJ, Moger $\mathrm{J}$, Tyler CR. Uptake and retention of microplastics by the shore crab Carcinus maenas. Environmental Science and Technology. 2014;48(15):8823-8830.

9. Yñiguez AT, Maister J, Villanoy CL, et al. Insights into the dynamics of harmful algal blooms in a tropical estuary through an integrated hydrodynamic-Pyrodiniumshellfish model. Harmful Algae. 2018;80:1-14. doi:10.1016/j.hal.2018.08.010.

10. Li J, Yang D, Li L, Jabeen K, Shi H. Microplastics in commercial bivalves from China. Environmental Pollution. 2015;207:190-195.

11. Li J, Qu X, Su L, Zhang W, Yang D, Kolandhasamy P, 
Li D. Microplastics in mussels along the coastal waters of China. Environmental Pollution. 2016;214:177-184.

12. Otaka I, Kumagai K, Inagaki Y, Shimoyama M, Saegusa K, Hara T. Simple and inexpensive software designed for the evaluation of color. American Journal of Ophthalmology. 2002;133(1):140-142.

13. Kershaw PJ, Turra A, Galgani F. Guidelines or the monitoring and assessment of plastic litter and microplastics in the ocean. GESAMP (IMO/FAO/UNESCO-

IOC/UNIDO/WMO/IAEA/UN/UNEP/UNDP/ISA Joint Group of Experts on the Scientific Aspects of Marine Environmental Protection). 2019;99:130.

14. Bilugan QM, Limbago JS, Gutierrez RL. Detection and quantification of microplastics from cultured green mussel Perna viridis in Bacoor Bay, Cavite, Philippines. Sustinere Journal of Environment and Sustainability. 2021;5(2):64-145.

15. Nam PN, Tuan PQ, Thuy DT, Quynh LTP, Amiard F. Contamination of microplastic in bivalve: first evaluation in Vietnam. Vietnam Journal of Earth Sciences. 2019;41(3):252-258. https://doi.org/10.15625/08667187/41/3/13925.

16. Qu X, Su L, Li H, Liang M, Shi H. Assessing the relationship between the abundance and properties of microplastics in water and in mussels. Science of The Total Environment. 2018;621:679-686.

17. Li J, Green C, Reynolds A, Shi H, Rotchell JM. Microplastics in mussels sampled from coastal waters and supermarkets in the United Kingdom. Environmental Pollution. 2018;241:35-44.

18. Digka N, Tsangaris C, Torre M, Anastasopoulou A, Zeri C. Microplastics in mussels and fish from the Northern Ionian Sea. Marine Pollution Bulletin. 2018;135:30-40.

19. European Food Safety Authority. EFSA Journal published by John Wiley and Sons Ltd on behalf of European Food Safety Authority. 2016.

20. Catarino AI, Macchia V, Sanderson WG, Thompson RC, Henry TB. Low levels of microplastics (MP) in wild mussels indicate that MP ingestion by humans is minimal compared to exposure via household fibres fallout during a meal. Environmental Pollution. 2018;237:675-684.

21. Meghan J. The scoop on Siloxane. Force of Nature. 2021; accessed $\quad 10 \quad$ November 2021, https://www.forceofnatureclean.com/chemical-freeliving-siloxanes/>

22. Filella M. Antimony and PET bottles: checking facts. Chemosphere. 2020;261:127732.

23. Bergmann M, Gutow L, Klages M. Marine Anthropogenic Litter. Edn 1, Springer, Cham. 2015;XVIII:447. https://doi.org/10.1007/978-3-319$16510-3$. 